\title{
Bibliometric Analysis of the Scientific Literature on Rheumatoid Arthritis-Associated Interstitial Lung Disease
}

\author{
Yuan Zhang, ${ }^{1,2,3}$ Tingxiao Zhao, ${ }^{1,2}$ Tianjin $W u,{ }^{1,2,4}$ Wei Huang, ${ }^{1,2,5}$ Teng Wu, ${ }^{1,2,4}$ \\ Yunjuan Shi, 1,2,3 and Zhenhua Ying (D) 1,2,3,4,5 \\ ${ }^{1}$ Zhejiang Provincial People's Hospital, Hangzhou, Zhejiang, China \\ ${ }^{2}$ Hangzhou Medical College People's Hospital, Hangzhou, Zhejiang, China \\ ${ }^{3}$ Bengbu Medical College, Bengbu, Anhui, China \\ ${ }^{4}$ Zhejiang Chinese Medical University, Hangzhou, Zhejiang, China \\ ${ }^{5}$ Qingdao University, Qingdao, Shandong, China \\ Correspondence should be addressed to Zhenhua Ying; yingzh2021@163.com
}

Received 26 August 2021; Accepted 8 November 2021; Published 20 December 2021

Academic Editor: Wen Ying Yu

Copyright (c) 2021 Yuan Zhang et al. This is an open access article distributed under the Creative Commons Attribution License, which permits unrestricted use, distribution, and reproduction in any medium, provided the original work is properly cited.

Background. In recent years, the number of studies on rheumatoid arthritis-related interstitial lung disease (RA-ILD) has been increasing, which has led to many publications on this topic. Our purpose is to identify research trends in RA-ILD and analyze the most-cited RA-ILD-related high-quality scientific publications. Methods. All publications on RA-ILD in the Core Collection database of Web of Science were searched. The publication year, country, institution, total citations, and journal were extracted and analyzed. We used VOSviewer software or an online bibliometric analysis platform for cooccurrence analysis of the keywords, institutions, and countries involved. The 100 most frequently cited RA-ILD publications were analyzed. Results. In total, 596 publications related to RA-ILD were obtained. Over time, the frequency of RA-ILD publications has increased. Globally, the United States provides the most publications on RA-ILD $(n=195)$. The institution with the highest publication output was the Mayo Clinic $(n=43)$. The journal "Annals of the Rheumatic Diseases" published most with 93 articles and received 338 citations. A clinical description was the most common research topic in RA-ILD-related publications. Conclusions. In recent years, there has been an increasing number of studies on RA-ILD, and related publications have increased rapidly. This study is the first bibliometric study of RA-ILD-related publications. It can be used as a guide for clinicians and can help researchers choose research directions of interest in this field.

\section{Introduction}

Rheumatoid arthritis (RA) is a systemic autoimmune disease characterized by articular and extra-articular manifestations affecting approximately $1-2 \%$ of the general population [1]. Interstitial lung disease (ILD) is an extra-articular manifestation of RA, which occurs frequently in up to $80 \%$ of patients with RA. This may be the result of chronic immune activation and inflammation in RA, or the pulmonary toxicity caused by immunomodulatory drugs used to treat RA [2-6]. The prevalence of RA-ILD ranges from $1 \%$ to $58 \%$, depending on the diagnostic means used and the severity in the RA population studied $[6,7]$. Currently, ILD is the second leading cause of death in patients with RA after car- diovascular disease [8]. Research on RA-ILD has increased to include its natural history, pathogenesis, radiological evaluation, clinical manifestations, and treatment [9-12]. However, the trend of RA-ILD research is unclear, and the most influential research in this field has not been systematically determined. Therefore, our purpose was to provide a bibliometric study of publications on RA-ILD.

Bibliometric analysis is a convenient and reliable statistical method that can quantitatively and qualitatively evaluate research trends in the research field. This analysis has long been used in the field of medical research and has been widely accepted by scientific researchers [13-15]. To the best of our knowledge, no bibliometric studies on RA-ILD have been published to date. Therefore, in this study, we use 
bibliometric statistical methods to identify the most influential publications and analyze the research status and trends in the RA-ILD research field.

\section{Materials and Methods}

2.1. Datasource. All the data of this study were obtained from articles retrieved from the core collection database of Web of Science on July 1, 2021.

2.2. Search Strategy. The retrieval steps and strategies were as follows: Title $=$ rheumatoid arthritis AND Title $=$ (interstitial lung disease OR interstitial pneumonia) AND Language = English AND Document type = (review OR article) AND Time span $=1980$ to 2021 .

2.3. Statistical Tools. VOSviewer, an online bibliometric analysis platform (https://bibliometric.com), and Excel software were used to extract and analyze all data. VOSviewer is a software that is usually used to visually analyze the collaborative network between countries, institutions, and authors and cocitation of keyword clusters to analyze research trends and hotspots. The role of the online bibliometric analysis platform is similar to that of VOSviewer. Excel software was used to extract and analyze various details of the publication, including author, title, journal, year of publication, institution, country, journal impact factors, and number of total citations.

2.4. Data Extraction. According to the retrieval steps and strategies, the two authors independently fetched the article information and discussed the differences until they reached a consensus. Data were obtained from the core collection database of Web of Science, and the publication information was extracted and analyzed using Excel, online bibliometric analysis, and VOSviewer software.

\section{Results}

3.1. Publication Analysis. A total of 596 RA-ILD research articles were found in the core collection database of the Web of Science. The number of articles increased from 1981 to 2021 (Figure 1(a)). Quantitative analysis shows that in the past 10 years, global research on RA-ILD has increased rapidly, from four articles from 1981 to 1985 to 326 articles from 2016 to 2020 . This result shows that RAILD has attracted increasing attention, and the research process of RA-ILD continues to accelerate.

3.2. Countries Analysis. These articles cover 46 countries and regions. Globally, the United States (US) published the most studies $(n=195)$, followed by Japan $(n=105)$, the United Kingdom $(n=66)$, Spain $(n=58)$, China $(n=49)$, Italy $(n=40)$, South Korea $(n=32)$, France $(n=23)$, Mexico $(n=22)$, and Canada $(n=14)$ (Figures 1(b) and 1(c)).

The online bibliometric analysis platform was used to analyze cooperative relations between countries. The visual analysis shows that the USA has always been the center of RA-ILD research in the world, and Japan, France, China, and South Korea have been found to be potential research powers. (Figure 1(d)).

3.3. Institutions Analysis. All the publications involve 1000 institutions. The results show that many institutions in the United States actively participate in RA-ILD research. The 10 most productive institutions internationally were Mayo Clinic $(n=43)$, National Jewish Health $(n=41)$, Brigham and Women's Hospital $(n=31)$, Colorado State University $(n=31)$, University of California, San Francisco $(n=19)$, University of Ulsan ( $n=19)$, University of Modena and Reggio Emilia $(n=17)$, Harvard Medical School $(n=15)$, Queen Elizabeth's Hospital $(n=15)$, and University of Miami $(n=15)$, respectively (Figure $2(\mathrm{a})$ ). According to the citation report, Mayo Clinic's articles were cited the most, namely, 1408 times, followed by the National Jewish Health, which was cited 858 times, and the University of California, San Francisco, 851 (Figure 2(b)).

VOSviewer software was used to analyze the extent of cooperative relations between institutions. The institution with the most links, i.e., the highest link strength was recorded by the National Jewish Health Organization $(n=131)$, followed by the University of Colorado $(n=123$ ), Mayo Clinic ( $n=119)$, and Brigham and Women's Hospital $(n=117)$. In the VOSviewer software, the width of the line reflects the close relationship of interinstitution cooperation. The National Jewish Health had close collaborations with the University of Colorado and Mayo Clinic. Mayo Clinic had large collaborations with National Jewish Health, University of Colorado, Brigham and Women's Hospital, and Harvard Medical School (Figure 2(c)).

3.4. Journals Analysis. All 596 articles in this study were published in 123 journals. Among these, the journals which had published at least 20 articles on the topic accounted for $73.8 \%$ of the total (Table 1). The five journals with the most articles on the topic were Annals of the Rheumatic Diseases, Arthritis \& Rheumatology, American Journal of Respiratory and Critical Care Medicine, Rheumatology, and Arthritis and Rheumatism. Moreover, articles in the Annals of the Rheumatic Diseases have been cited the most. More than 20 journals published on RA-ILD, and the average impact factor was 11.8, indicating a high level of reliability of the included studies.

3.5. Research Status and Analysis. VOSviewer software was used to analyze the cooccurrence analysis of keywords in the RA-ILD research articles. When the minimum number of keywords appearing in the publication was set to five, 72 keywords were selected and divided into four clusters:

"Clinical-Features," "Pathological-Features," "Treatment," and "Prevalence and mortality." In the "ClinicalFeatures" cluster, the most common keywords were "pneumonia," "idiopathic pulmonary-fibrosis," and "prognosis." In the "Pathological-Features" cluster, the most frequent keywords were "rheumatoid arthritis," "interstitial lung disease," and "fibrosis." In the "treatment" cluster, the most frequent keywords were "classification," "criteria," and "safety." In the "prevalence and mortality" cluster, the most 


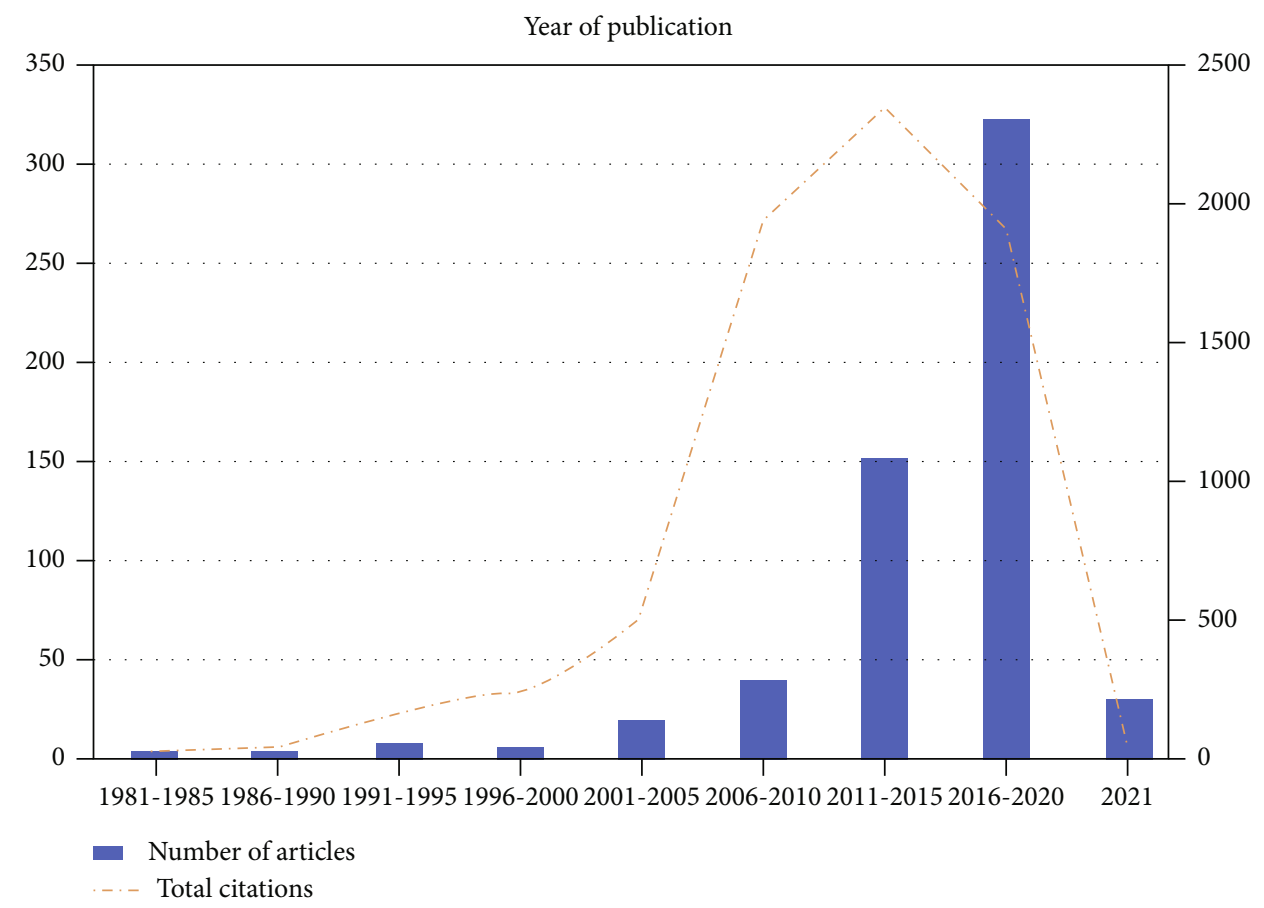

(a)

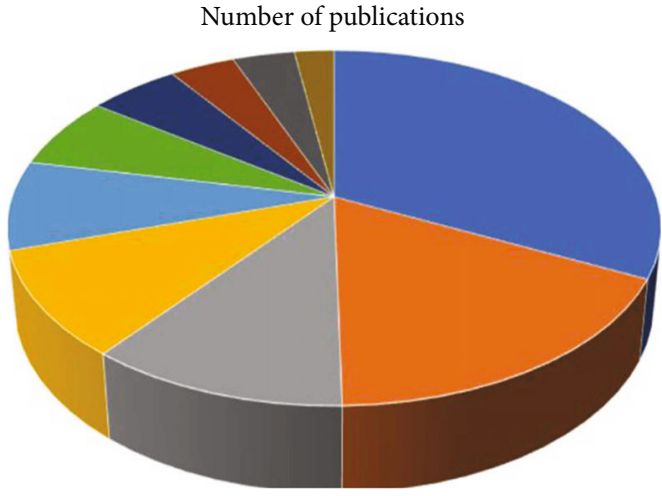
- United states (195)
Italy (40)
- Japan (105)
- South korea (32)
- United kingdom (66)
- France (23)
- Spain (58)
- Mexico (22)
- China (49)
- Canada (14)

(b)

Figure 1: Continued. 


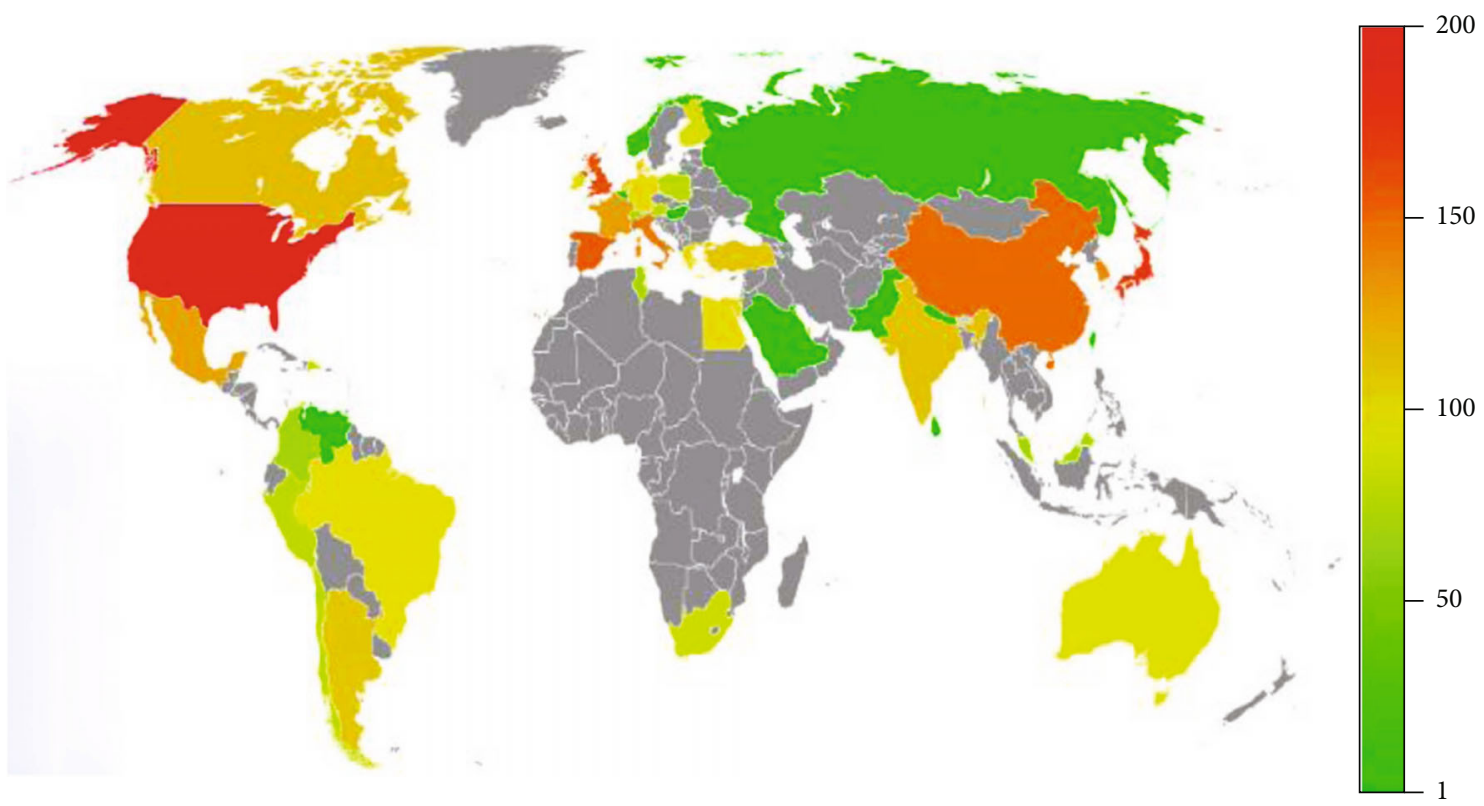

(c)

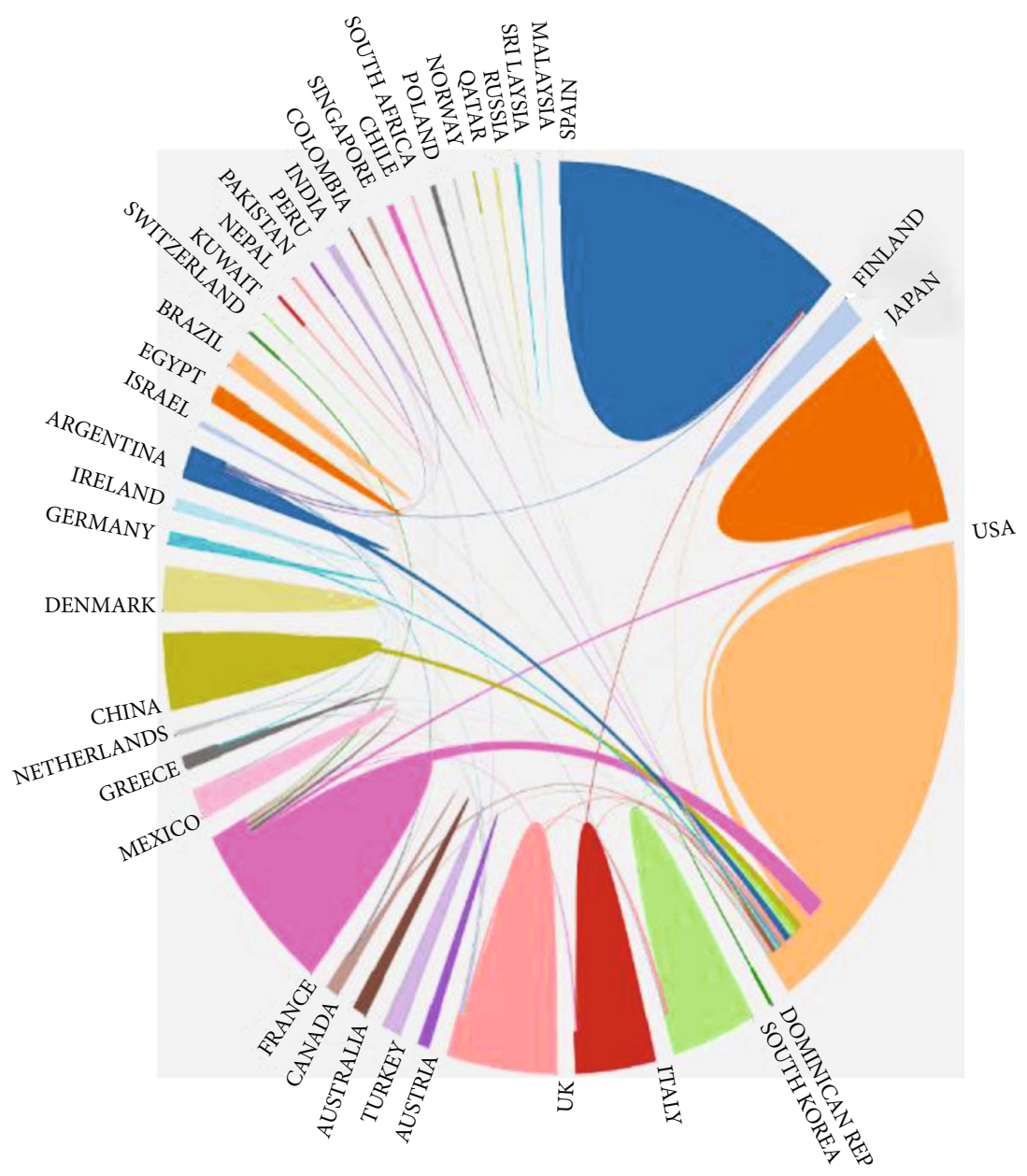

(d)

Figure 1: Overview of publications. (a) Number of publications and citations from 1981 to 2021. (b) Sources of publications. (c) Top 10 countries. (d) International collaborations. 


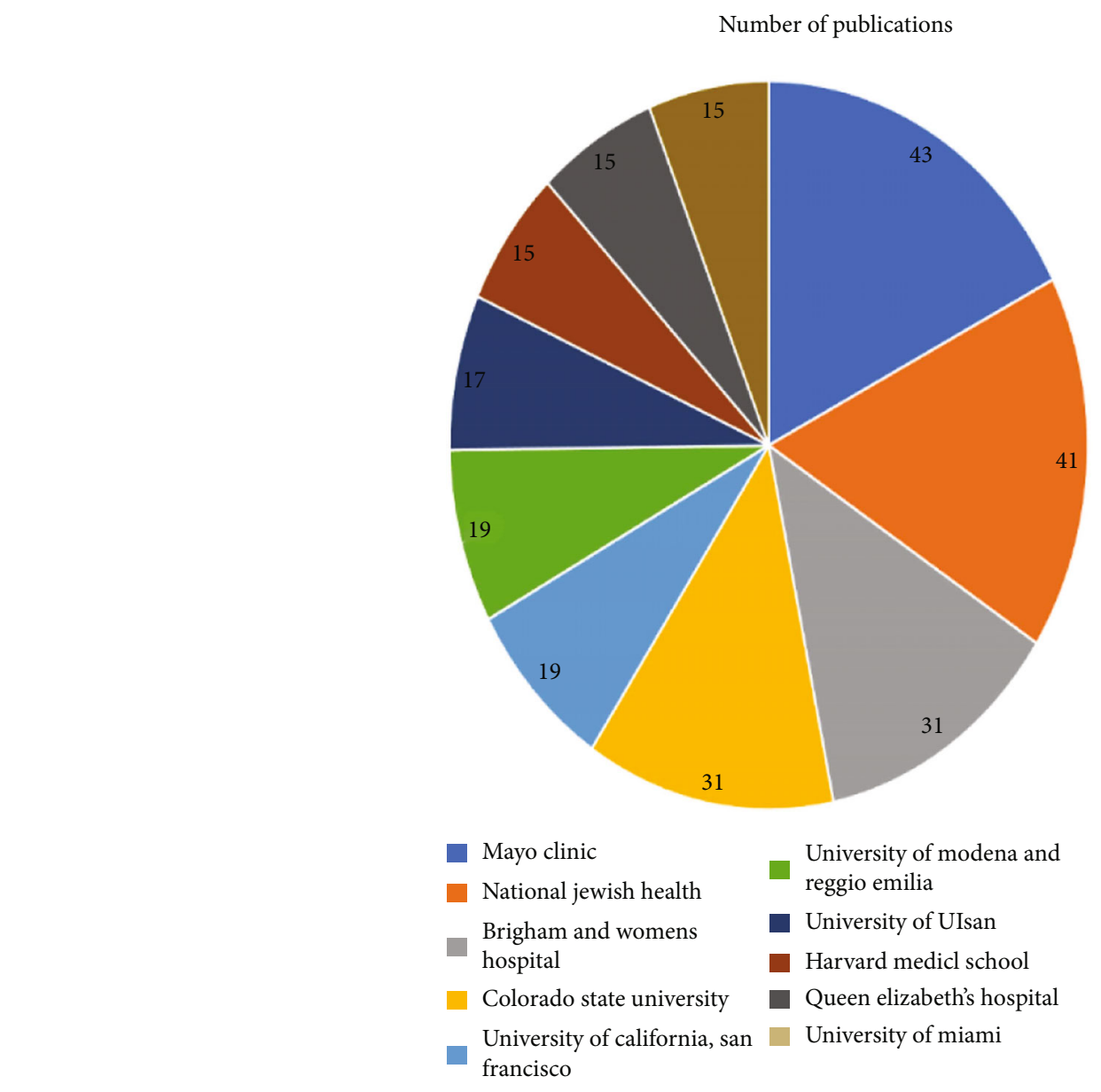

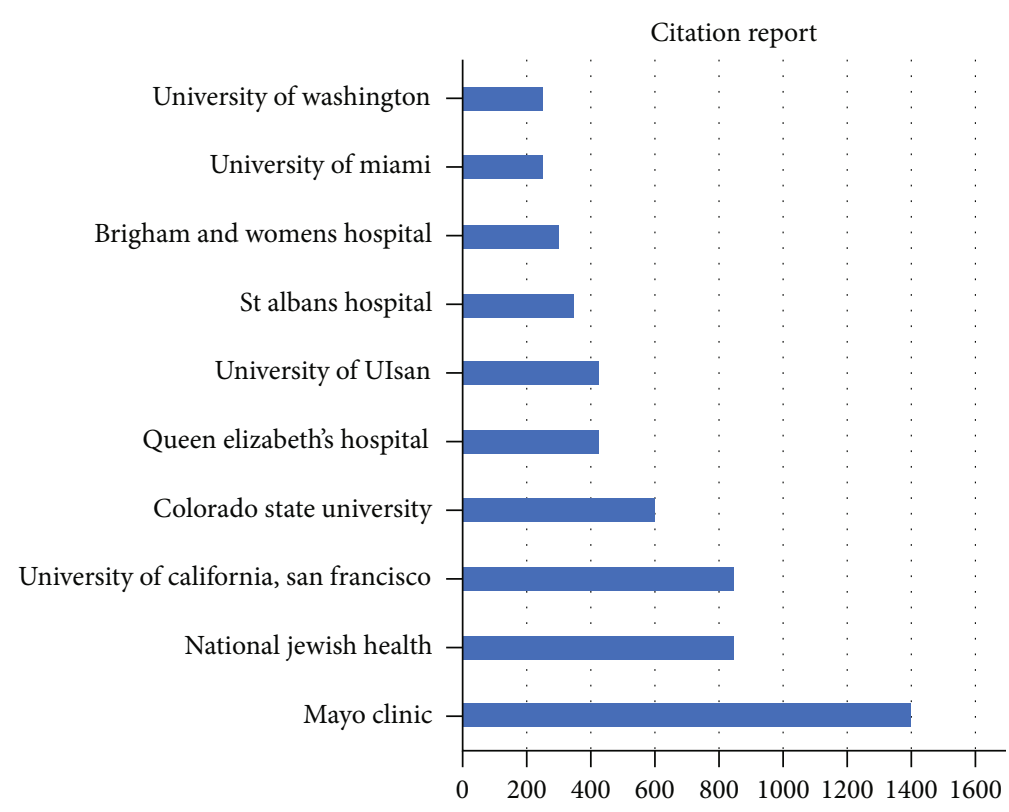

(b)
Tokyo metropolitan tama med ct

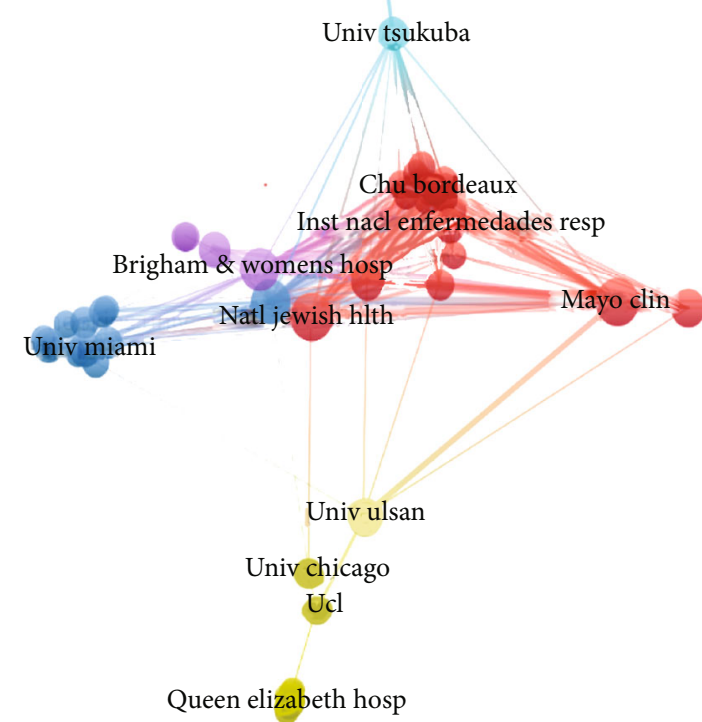

(c)

Figure 2: Highest impact institutions. (a) The top 10 institutions (publications). (b) The top 10 institutions (citations). (c) Institutional collaborations. 
TABLE 1: Active journals on rheumatoid arthritis-associated interstitial lung disease.

\begin{tabular}{|c|c|c|c|c|}
\hline Journal & Article & Total citation & Mean citation & Impact factor \\
\hline Annals of the Rheumatic Diseases & 93 & 338 & 3.63 & 19.103 \\
\hline Arthritis \& Rheumatology & 75 & 219 & 2.92 & 10.995 \\
\hline American Journal of Respiratory and Critical Care Medicine & 53 & 514 & 9.70 & 21.405 \\
\hline Rheumatology & 38 & 710 & 18.68 & 20.543 \\
\hline Arthritis and Rheumatism & 36 & 552 & 15.33 & 5.532 \\
\hline European Respiratory Journal & 30 & 537 & 17.90 & 16.671 \\
\hline Clinical Rheumatology & 18 & 248 & 13.78 & 4.098 \\
\hline Chest & 12 & 485 & 40.42 & 2.878 \\
\hline Internal Medicine & 11 & 156 & 14.18 & 2.048 \\
\hline Clinical and Experimental Rheumatology & 10 & 98 & 9.80 & 4.473 \\
\hline Respiratory Medicine & 8 & 258 & 32.25 & 3.772 \\
\hline Modern Rheumatology & 8 & 108 & 13.50 & 3.023 \\
\hline Seminars in Arthritis and Rheumatism & 6 & 208 & 34.67 & 5.532 \\
\hline Rheumatology International & 6 & 154 & 25.67 & 2.631 \\
\hline Journal of Rheumatology & 6 & 147 & 24.50 & 4.666 \\
\hline New England Journal of Medicine & 6 & 133 & 22.17 & 91.245 \\
\hline PLos one & 6 & 127 & 21.17 & 3.24 \\
\hline Scandinavian Journal of Rheumatology & 6 & 104 & 17.33 & 3.641 \\
\hline Respirology & 6 & 92 & 15.33 & 6.424 \\
\hline JCR-Journal of Clinical Rheumatology & 6 & 26 & 4.33 & 3.517 \\
\hline
\end{tabular}

frequent keywords were "prevalence," "mortality," and "risk" (Figure 3(a)).

To better understand the dynamic process of the RA-ILD research trends, we evaluated the evolution of the keywords (Figure 3(b)). We assigned colors based on the year the keyword appears in the article. For example, the yellow keyword appears later than the purple keyword. In the early stages, "idiopathic pulmonary fibrosis," "alveolitis," and "systemic sclerosis" were the main topics. Trends in recent years show that the terms "management," "predictors," "inflammation," and "progress" are becoming more and more popular.

3.6. The 100 Most-Cited Publications. The 100 most-cited publications on RA-ILD were published between 1984 and 2020 (Table 2). The analysis indicated that 2001-2005 was the period when most of these studies were published, with 41 publications, followed by 2016-2020, with 29 publications (Figure 4(a)).

The 100 most-cited articles were from 18 countries and regions. Thirty-four articles were published by authors from the USA, followed by Japan $(n=20)$, the United Kingdom $(n=11)$, China $(n=7)$, Italy $(n=5)$, Canada $(n=3)$, Austria $(n=3)$, Spain, France, and Germany $(n=2)$, and Mexico, Argentina, Australia, Bangladesh, Denmark, Finland, and Ireland $(n=1)$ (Figure 4(b)).

Of these 100 articles, the Mayo Clinic Medicine and National Jewish Health each generated seven publications, resulting in their being the most represented institutions on this topic, followed by the University of California in San Francisco $(n=5)$ and Queen Elizabeth Hospital $(n=4)$ (Figure 4(c)).
Overall, there were 52 different journals which published the 100 articles. "Rheumatology" was the most productive journal, with 8 articles and 632 citations, followed by "Arthritis and Rheumatism," with five articles and 529 citations (Table 3).

When considering the individual authors' academic contributions, Jay H Ryu, provided 11 publications, followed by Joyce C Lee and Eric L Matteson, each with 8 publications (Table 4).

The most common research topic on RA-ILD addressed the clinical description $(n=44)$, followed by clinical research $(n=13)$, diagnosis $(n=8)$, mortality $(n=7)$, and risk factors $(n=6)$ (Figure $4(\mathrm{~d})$ ).

\section{Discussion}

ILD is one of the most common complications of RA and poses a great challenge to clinicians and researchers [16]. The prevalence of RA-ILD ranged from $1 \%$ to $58 \%$ in the different studies, which was related to the diagnostic techniques used and the study population that was included [17-19]. According to the literature, there are many risk factors for RA-ILD, including male sex, smoking, older age, high disease activity of RA, characteristics of extra-articular diseases (subcutaneous nodules), and seropositive RA autoantibodies (rheumatoid factor and anticitrulline protein antibody) [2, 20-23]. The most common presenting symptoms include exertional dyspnea, tachypnea, and bibasilar inspiratory crackles. In the advanced stages of the disease, symptoms of cyanosis, edema, and pulmonary hypertension may occur, leading to a reduced quality of life [24]. 


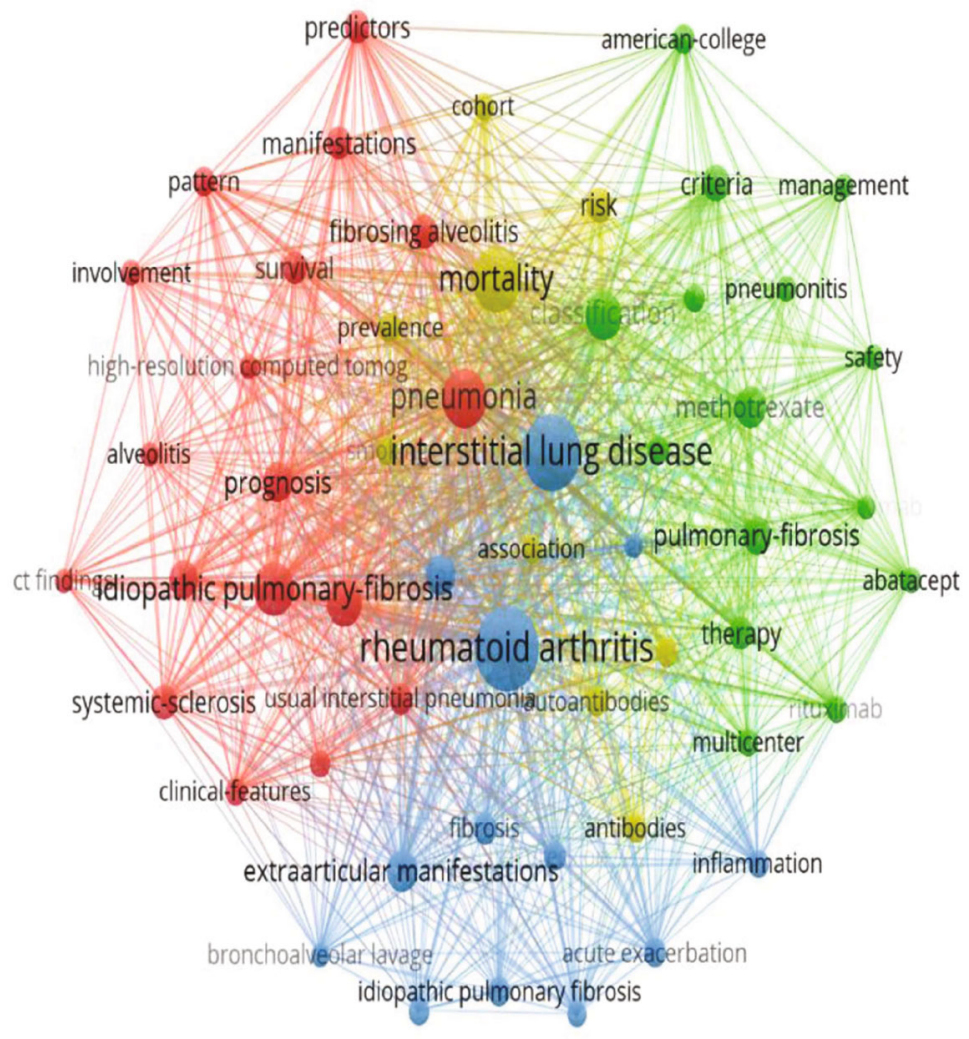

(a)

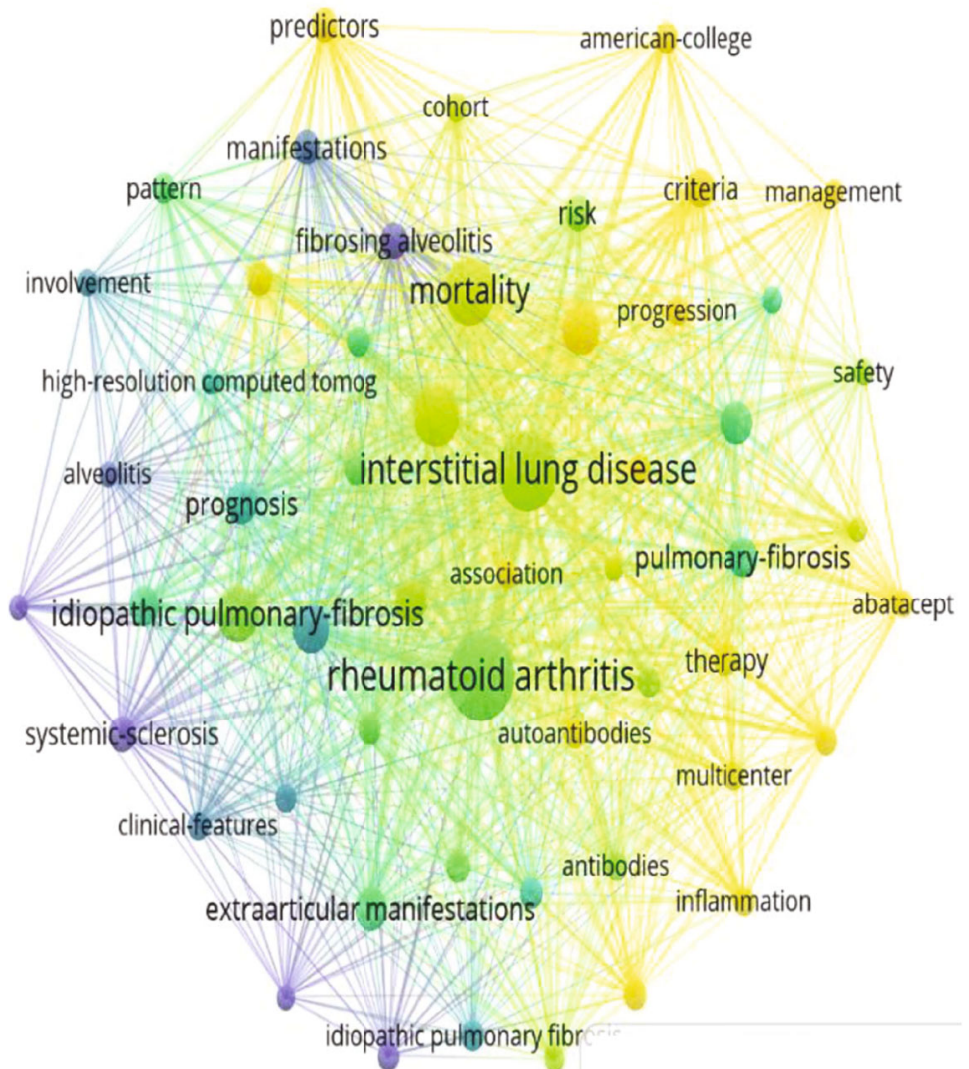

(b)

Figure 3: Keyword analysis. (a) Cluster analysis of keywords. (b) Evolution of keyword frequency. 
TABLE 2: The top 100 cited publications on rheumatoid arthritis-associated interstitial lung disease.

\begin{tabular}{|c|c|c|c|c|c|c|}
\hline Rank & Title & Author & Journal & Year & $\begin{array}{l}\text { Total } \\
\text { citation }\end{array}$ & $\begin{array}{l}\text { Citation/ } \\
\text { year }\end{array}$ \\
\hline 1 & $\begin{array}{l}\text { Incidence and mortality of interstitial lung disease in } \\
\text { rheumatoid arthritis: a population-based study }\end{array}$ & Bongartz, T. & Arthritis and Rheumatism & 2010 & 324 & 27 \\
\hline 2 & $\begin{array}{l}\text { Usual interstitial pneumonia in rheumatoid arthritis- } \\
\text { associated interstitial lung disease }\end{array}$ & Kim, E. J. & $\begin{array}{l}\text { European Respiratory } \\
\text { Journal }\end{array}$ & 2010 & 283 & 23.58 \\
\hline 3 & $\begin{array}{l}\text { Histopathologic pattern and clinical features of rheumatoid } \\
\text { arthritis associated interstitial lung disease }\end{array}$ & Lee, H. K & Chest & 2005 & 245 & 14.41 \\
\hline 4 & $\begin{array}{l}\text { Rheumatoid arthritis-interstitial lung disease-associated } \\
\text { mortality }\end{array}$ & Olson, A. L. & $\begin{array}{l}\text { American Journal of } \\
\text { Respiratory and Critical } \\
\text { Care Medicine }\end{array}$ & 2011 & 222 & 20.18 \\
\hline 5 & Interstitial lung disease in recent onset rheumatoid arthritis & Gabbay, E. & $\begin{array}{l}\text { American Journal of } \\
\text { Respiratory and Critical } \\
\text { Care Medicine }\end{array}$ & 1997 & 220 & 8.8 \\
\hline 6 & $\begin{array}{l}\text { Rheumatoid arthritis-related interstitial lung disease: } \\
\text { associations, prognostic factors and physiological and } \\
\text { radiological characteristics-a large multicentre UK study }\end{array}$ & Kelly, C. A. & Rheumatology & 2014 & 205 & 25.63 \\
\hline 7 & $\begin{array}{c}\text { Progressive preclinical interstitial lung disease in } \\
\text { rheumatoid arthritis }\end{array}$ & $\begin{array}{l}\text { Gochuico, B. } \\
\text { R. }\end{array}$ & $\begin{array}{l}\text { Archives of Internal } \\
\text { Medicine }\end{array}$ & 2008 & 198 & 14.14 \\
\hline 8 & $\begin{array}{l}\text { Rheumatoid arthritis-associated interstitial lung disease the } \\
\text { relevance of histopathologic and radiographic pattern }\end{array}$ & Kim, E. J. & Chest & 2009 & 189 & 14.54 \\
\hline 9 & $\begin{array}{l}\text { Interstitial lung disease has a poor prognosis in rheumatoid } \\
\text { arthritis: results from an inception cohort }\end{array}$ & Koduri, G. & Rheumatology & 2010 & 149 & 12.42 \\
\hline 10 & $\begin{array}{c}\text { Interstitial lung diseases induced or exacerbated by } \\
\text { DMARDS and biologic agents in rheumatoid arthritis: A } \\
\text { systematic literature review }\end{array}$ & Roubille, C. & $\begin{array}{l}\text { Seminars in Arthritis and } \\
\text { Rheumatism }\end{array}$ & 2014 & 126 & 15.75 \\
\hline 11 & $\begin{array}{l}\text { Predictors of mortality in rheumatoid arthritis-associated } \\
\text { interstitial lung disease }\end{array}$ & Solomon, J. J. & $\begin{array}{l}\text { European Respiratory } \\
\text { Journal }\end{array}$ & 2016 & 124 & 20.67 \\
\hline 12 & $\begin{array}{l}\text { MUC5B promoter variant and rheumatoid arthritis with } \\
\text { interstitial lung disease }\end{array}$ & Juge, P. A. & $\begin{array}{l}\text { New England Journal of } \\
\text { Medicine }\end{array}$ & 2018 & 108 & 27 \\
\hline 13 & $\begin{array}{c}\text { Influence of anti-TNF therapy on mortality in patients with } \\
\text { rheumatoid arthritis-associated interstitial lung disease: } \\
\text { results from the British Society for Rheumatology Biologics } \\
\text { Register }\end{array}$ & Dixon, W. G. & $\begin{array}{c}\text { Annals of the Rheumatic } \\
\text { Diseases }\end{array}$ & 2010 & 108 & 9 \\
\hline 14 & $\begin{array}{l}\text { High-resolution computed-tomography of the lungs in } \\
\text { patients with rheumatoid-arthritis and interstitial lung- } \\
\text { disease }\end{array}$ & Mcdonagh, J & $\begin{array}{l}\text { British Journal of } \\
\text { Rheumatology }\end{array}$ & 1994 & 102 & 3.64 \\
\hline 15 & $\begin{array}{l}\text { Leflunomide use and the risk of interstitial lung disease in } \\
\text { rheumatoid arthritis }\end{array}$ & Suissa, S. & Arthritis and Rheumatism & 2006 & 95 & 5.94 \\
\hline 16 & $\begin{array}{l}\text { Different risk factors between interstitial lung disease and } \\
\text { airway disease in rheumatoid arthritis }\end{array}$ & Mori, S. & Respiratory Medicine & 2012 & 89 & 8.9 \\
\hline 17 & $\begin{array}{l}\text { A population-based cohort study of rheumatoid arthritis- } \\
\text { associated interstitial lung disease: comorbidity and } \\
\text { mortality }\end{array}$ & Hyldgaard, C. & $\begin{array}{c}\text { Annals of the Rheumatic } \\
\text { Diseases }\end{array}$ & 2017 & 83 & 16.6 \\
\hline 18 & $\begin{array}{c}\text { Predictors of mortality in rheumatoid arthritis-related } \\
\text { interstitial lung disease }\end{array}$ & Assayag, D. & Respirology & 2014 & 83 & 10.38 \\
\hline 19 & $\begin{array}{l}\text { Rheumatoid arthritis-associated interstitial lung disease: } \\
\text { radiologic identification of usual interstitial pneumonia } \\
\text { pattern }\end{array}$ & Assayag, D. & Radiology & 2014 & 77 & 9.63 \\
\hline 20 & $\begin{array}{l}\text { Correlation between HRCT findings, pulmonary function } \\
\text { tests and bronchoalveolar lavage cytology in interstitial } \\
\text { lung disease associated with rheumatoid arthritis }\end{array}$ & Biederer, J. & European Radiology & 2004 & 74 & 4.11 \\
\hline 21 & $\begin{array}{l}\text { Association of fine specificity and repertoire expansion of } \\
\text { anticitrullinated peptide antibodies with rheumatoid } \\
\text { arthritis associated interstitial lung disease }\end{array}$ & Giles, J. T. & $\begin{array}{c}\text { Annals of the Rheumatic } \\
\text { Diseases }\end{array}$ & 2014 & 71 & 8.88 \\
\hline
\end{tabular}


TABle 2: Continued.

\begin{tabular}{|c|c|c|c|c|c|c|}
\hline Rank & Title & Author & Journal & Year & $\begin{array}{c}\text { Total } \\
\text { citation }\end{array}$ & $\begin{array}{c}\text { Citation/ } \\
\text { year }\end{array}$ \\
\hline 22 & $\begin{array}{c}\text { Fibrosing interstitial pneumonia predicts survival in } \\
\text { patients with rheumatoid arthritis-associated interstitial } \\
\text { lung disease (RA-ILD) }\end{array}$ & Solomon, J. J. & Respiratory Medicine & 2013 & 71 & 7.89 \\
\hline 23 & $\begin{array}{l}\text { Effect of rituximab on the progression of rheumatoid } \\
\text { arthritis-related interstitial lung disease: } 10 \text { years' } \\
\text { experience at a single centre }\end{array}$ & Yusof, M. M. & Rheumatology & 2017 & 69 & 13.8 \\
\hline 24 & $\begin{array}{l}\text { Shared genetic predisposition in rheumatoid arthritis- } \\
\text { interstitial lung disease and familial pulmonary fibrosis }\end{array}$ & Juge, P. A. & $\begin{array}{l}\text { European Respiratory } \\
\text { Journal }\end{array}$ & 2017 & 69 & 13.8 \\
\hline 25 & $\begin{array}{l}\text { Rheumatoid arthritis (RA)-specific autoantibodies in } \\
\text { patients with interstitial lung disease and absence of } \\
\text { clinically apparent articular RA }\end{array}$ & $\begin{array}{l}\text { Gizinski, A. } \\
\text { M. }\end{array}$ & Clinical Rheumatology & 2009 & 68 & 5.23 \\
\hline 26 & $\begin{array}{c}\text { Detection of rheumatoid arthritis-interstitial lung disease is } \\
\text { enhanced by serum biomarkers }\end{array}$ & Doyle, T. J. & $\begin{array}{l}\text { American Journal of } \\
\text { Respiratory and Critical } \\
\text { Care Medicine }\end{array}$ & 2015 & 67 & 9.57 \\
\hline 27 & $\begin{array}{l}\text { Leflunomide-induced interstitial lung disease: prevalence } \\
\text { and risk factors in Japanese patients with rheumatoid } \\
\text { arthritis }\end{array}$ & Sawada, T. & Rheumatology & 2009 & 66 & 5.08 \\
\hline 28 & $\begin{array}{l}\text { Acute exacerbation in rheumatoid arthritis-associated } \\
\text { interstitial lung disease: a retrospective case control study }\end{array}$ & Hozumi, $\mathrm{H}$. & BMJ open & 2013 & 63 & 7 \\
\hline 29 & $\begin{array}{c}\text { The lung in rheumatoid arthritis focus on interstitial lung } \\
\text { disease }\end{array}$ & Spagnolo, $\mathrm{P}$. & Arthritis \& Rheumatology & 2018 & 62 & 15.5 \\
\hline 30 & $\begin{array}{c}\text { Abatacept in patients with rheumatoid arthritis and } \\
\text { interstitial lung disease: a national multicenter study of } 63 \\
\text { patients }\end{array}$ & $\begin{array}{l}\text { Fernandez- } \\
\text { Diaz, C. }\end{array}$ & $\begin{array}{l}\text { Seminars in Arthritis and } \\
\text { Rheumatism }\end{array}$ & 2018 & 62 & 15.5 \\
\hline 31 & $\begin{array}{c}\text { Rheumatoid arthritis (RA) associated interstitial lung } \\
\text { disease (ILD) }\end{array}$ & $\begin{array}{l}\text { O’Dwyer, D. } \\
\text { N. }\end{array}$ & $\begin{array}{l}\text { European Journal of Internal } \\
\text { Medicine }\end{array}$ & 2013 & 62 & 6.89 \\
\hline 32 & $\begin{array}{c}\text { Rheumatoid arthritis treatment and the risk of severe } \\
\text { interstitial lung disease }\end{array}$ & Wolfe, F. & $\begin{array}{l}\text { Scandinavian Journal of } \\
\text { Rheumatology }\end{array}$ & 2007 & 60 & 4 \\
\hline 33 & $\begin{array}{l}\text { Rheumatoid arthritis complicated with acute interstitial } \\
\text { pneumonia induced by leflunomide as an adverse reaction }\end{array}$ & Kamata, Y & Internal Medicine & 2004 & 56 & 3.11 \\
\hline 34 & $\begin{array}{l}\text { Morphologic and quantitative assessment of CD20+ B cell } \\
\text { infiltrates in rheumatoid arthritis-associated nonspecific } \\
\text { interstitial pneumonia and usual interstitial pneumonia }\end{array}$ & Atkins, S. R. & Arthritis and Rheumatism & 2006 & 55 & 3.44 \\
\hline 35 & $\begin{array}{c}\text { Biomarkers of rheumatoid arthritis-associated interstitial } \\
\text { lung disease }\end{array}$ & Chen, J. & Arthritis \& Rheumatology & 2015 & 54 & 7.71 \\
\hline 36 & $\begin{array}{l}\text { Acute exacerbation of preexisting interstitial lung disease } \\
\text { after administration of etanercept for rheumatoid arthritis }\end{array}$ & Hagiwara, K. & Journal of Rheumatology & 2007 & 52 & 3.47 \\
\hline 37 & $\begin{array}{c}\text { Nonspecific interstitial pneumonia pattern as pulmonary } \\
\text { involvement of rheumatoid arthritis }\end{array}$ & $\begin{array}{l}\text { Yoshinouchi, } \\
\mathrm{T}\end{array}$ & Rheumatology International & 2005 & 49 & 2.88 \\
\hline 38 & $\begin{array}{l}\text { Progressive decline of lung function in rheumatoid } \\
\text { arthritis-associated interstitial lung disease }\end{array}$ & $\begin{array}{l}\text { Zamora- } \\
\text { Legoff, J. A. }\end{array}$ & Arthritis \& Rheumatology & 2017 & 48 & 9.6 \\
\hline 39 & $\begin{array}{l}\text { Retrospective study of the clinical characteristics and risk } \\
\text { factors of rheumatoid arthritis-associated interstitial lung } \\
\text { disease }\end{array}$ & Zhang, Y. F. & Clinical Rheumatology & 2017 & 46 & 9.2 \\
\hline 40 & $\begin{array}{l}\text { Rheumatoid arthritis-interstitial lung disease in the United } \\
\text { States: prevalence, incidence, and healthcare costs and } \\
\text { mortality }\end{array}$ & Raimundo, K. & Journal of Rheumatology & 2019 & 45 & 15 \\
\hline 41 & $\begin{array}{c}\text { The multifaceted aspects of interstitial lung disease in } \\
\text { rheumatoid arthritis }\end{array}$ & Cavagna, L. & $\begin{array}{l}\text { Biomed Research } \\
\text { International }\end{array}$ & 2013 & 45 & 5 \\
\hline 42 & $\begin{array}{l}\text { Association of human leukocyte antigen with interstitial } \\
\text { lung disease in rheumatoid arthritis: a protective role for } \\
\text { shared epitope }\end{array}$ & Furukawa, H. & PLos one & 2012 & 45 & 4.5 \\
\hline
\end{tabular}


TABle 2: Continued.

\begin{tabular}{|c|c|c|c|c|c|c|}
\hline Rank & Title & Author & Journal & Year & $\begin{array}{l}\text { Total } \\
\text { citation }\end{array}$ & $\begin{array}{c}\text { Citation/ } \\
\text { year }\end{array}$ \\
\hline 43 & $\begin{array}{l}\text { Clinical and radiological features of acute-onset diffuse } \\
\text { interstitial lung diseases in patients with rheumatoid } \\
\text { arthritis receiving treatment with biological agents: } \\
\text { importance of Pneu }\end{array}$ & Kameda, H. & Internal Medicine & 2011 & 45 & 4.09 \\
\hline 44 & $\begin{array}{c}\text { Is incident rheumatoid arthritis interstitial lung disease } \\
\text { associated with methotrexate treatment? Results from a } \\
\text { multivariate analysis in the ERAS and ERAN inception } \\
\text { cohorts }\end{array}$ & Kiely, P. & BMJ open & 2019 & 44 & 14.67 \\
\hline 45 & $\begin{array}{l}\text { High resolution computed tomography pattern of usual } \\
\text { interstitial pneumonia in rheumatoid arthritis-associated } \\
\text { interstitial lung disease: relationship to survival }\end{array}$ & Yunt, Z. X. & Respiratory Medicine & 2017 & 44 & 8.8 \\
\hline 46 & $\begin{array}{l}\text { Interstitial lung disease in rheumatoid arthritis: recent } \\
\text { advances }\end{array}$ & Kim, D. S. & $\begin{array}{l}\text { Current Opinion in } \\
\text { Pulmonary Medicine }\end{array}$ & 2006 & 44 & 2.75 \\
\hline 47 & $\begin{array}{c}\text { Treatment of rheumatoid arthritis-associated interstitial } \\
\text { lung disease: a perspective review }\end{array}$ & Iqbal, $\mathrm{K}$. & $\begin{array}{l}\text { Therapeutic Advances in } \\
\text { Musculoskeletal Disease }\end{array}$ & 2015 & 43 & 6.14 \\
\hline 48 & $\begin{array}{l}\text { Clinical course and outcome of rheumatoid arthritis- } \\
\text { related usual interstitial pneumonia }\end{array}$ & Song, J. W. & $\begin{array}{l}\text { Sarcoidosis Vasculitis and } \\
\text { Diffuse Lung Diseases }\end{array}$ & 2013 & 42 & 4.67 \\
\hline 49 & $\begin{array}{c}\text { Increased levels of interleukin-33 associated with bone } \\
\text { erosion and interstitial lung diseases in patients with } \\
\text { rheumatoid arthritis }\end{array}$ & Zhu X. Y & Cytokine & 2012 & 42 & 4.2 \\
\hline 50 & $\begin{array}{c}\text { Incidence of and risk factors for interstitial pneumonia in } \\
\text { patients with rheumatoid arthritis in a large Japanese } \\
\text { observational cohort, IORRA }\end{array}$ & Shidara, K. & Modern Rheumatology & 2010 & 42 & 3.5 \\
\hline 51 & $\begin{array}{l}\text { Interstitial lung-disease in rheumatoid-arthritis - } \\
\text { assessment with high-resolution computed-tomography }\end{array}$ & Fujii, M & Journal of Thoracic Imaging & 1993 & 42 & 1.45 \\
\hline 52 & $\begin{array}{c}\text { Patterns of interstitial lung disease and mortality in } \\
\text { rheumatoid arthritis }\end{array}$ & $\begin{array}{l}\text { Zamora- } \\
\text { Legoff, J. A. }\end{array}$ & Rheumatology & 2017 & 41 & 8.2 \\
\hline 53 & $\begin{array}{l}\text { Standard and pocket-size lung ultrasound devices can } \\
\text { detect interstitial lung disease in rheumatoid arthritis } \\
\text { patients }\end{array}$ & Cogliati, C. & Rheumatology & 2014 & 41 & 5.13 \\
\hline 54 & $\begin{array}{c}\text { Potential risk of TNF inhibitors on the progression of } \\
\text { interstitial lung disease in patients with rheumatoid } \\
\text { arthritis }\end{array}$ & Nakashita, T. & BMJ open & 2014 & 41 & 5.13 \\
\hline 55 & $\begin{array}{l}\text { A fatal case of acute exacerbation of interstitial lung disease } \\
\text { in a patient with rheumatoid arthritis during treatment } \\
\text { with tocilizumab }\end{array}$ & Kawashiri, S. & Rheumatology International & 2012 & 41 & 4.1 \\
\hline 56 & $\begin{array}{c}\text { Interstitial lung disease in patients with rheumatoid } \\
\text { arthritis: comparison with cryptogenic fibrosing alveolitis } \\
\text { over } 5 \text { years }\end{array}$ & $\begin{array}{l}\text { Rajasekaran, } \\
\text { A. }\end{array}$ & Journal of Rheumatology & 2006 & 41 & 2.56 \\
\hline 57 & $\begin{array}{l}\text { Interstitial lung disease in patients with rheumatoid } \\
\text { arthritis: a comparison with cryptogenic fibrosing alveolitis }\end{array}$ & $\begin{array}{l}\text { Rajasekaran, } \\
\text { B. A. }\end{array}$ & Rheumatology & 2001 & 40 & 1.9 \\
\hline 58 & $\begin{array}{c}\text { A roadmap to promote clinical and translational research } \\
\text { in rheumatoid arthritis-associated interstitial lung disease a } \\
\text { dance promote clinical and translational research }\end{array}$ & Doyle, T. J. & Chest & 2014 & 39 & 4.88 \\
\hline 59 & $\begin{array}{c}\text { Rheumatoid arthritis-related interstitial lung disease (RA- } \\
\text { ILD): methotrexate and the severity of lung disease are } \\
\text { associated to prognosis }\end{array}$ & $\begin{array}{l}\text { Rojas- } \\
\text { serrano, J. }\end{array}$ & Clinical Rheumatology & 2017 & 38 & 7.6 \\
\hline 60 & $\begin{array}{c}\text { Rheumatoid arthritis associated interstitial lung disease: a } \\
\text { review }\end{array}$ & Assayag, D. & Medicina-Buenos Aires & 2014 & 38 & 4.75 \\
\hline 61 & $\begin{array}{c}\text { Sonographic assessment of interstitial lung disease in } \\
\text { patients with rheumatoid arthritis, systemic sclerosis and } \\
\text { systemic lupus erythematosus }\end{array}$ & $\begin{array}{l}\text { Moazedi- } \\
\text { Fuerst, F. }\end{array}$ & $\begin{array}{l}\text { Clinical and Experimental } \\
\text { Rheumatology }\end{array}$ & 2015 & 37 & 5.29 \\
\hline
\end{tabular}


TABle 2: Continued.

\begin{tabular}{|c|c|c|c|c|c|c|}
\hline Rank & Title & Author & Journal & Year & $\begin{array}{l}\text { Total } \\
\text { citation }\end{array}$ & $\begin{array}{l}\text { Citation/ } \\
\text { year }\end{array}$ \\
\hline 62 & $\begin{array}{c}\text { Association of cross-reactive antibodies targeting peptidyl- } \\
\text { arginine deiminase } 3 \text { and } 4 \text { with rheumatoid arthritis- } \\
\text { associated interstitial lung disease }\end{array}$ & Giles, J. T. & PLos one & 2014 & 37 & 4.63 \\
\hline 63 & $\begin{array}{c}\text { Clinical and laboratory factors associated with interstitial } \\
\text { lung disease in rheumatoid arthritis }\end{array}$ & Restrepo, J. F. & Clinical Rheumatology & 2015 & 35 & 5 \\
\hline 64 & $\begin{array}{c}\text { Rheumatoid arthritis interstitial lung disease: } \\
\text { mycophenolate mofetil as an antifibrotic and disease- } \\
\text { modifying antirheumatic drug }\end{array}$ & $\begin{array}{l}\text { Saketkoo, L. } \\
\text { A. }\end{array}$ & $\begin{array}{l}\text { Archives of Internal } \\
\text { Medicine }\end{array}$ & 2008 & 34 & 2.43 \\
\hline 65 & $\begin{array}{c}\text { Survival and quality of life in rheumatoid arthritis- } \\
\text { associated interstitial lung disease after lung } \\
\text { transplantation }\end{array}$ & Yazdani, A. & $\begin{array}{l}\text { Journal of Heart and Lung } \\
\text { Transplantation }\end{array}$ & 2014 & 33 & 4.13 \\
\hline 66 & $\begin{array}{c}\text { Rheumatoid arthritis-associated autoantibodies and } \\
\text { subclinical interstitial lung disease: the multi-ethnic study } \\
\text { of atherosclerosis }\end{array}$ & $\begin{array}{l}\text { Bernstein, E. } \\
\text { J. }\end{array}$ & Thorax & 2016 & 32 & 5.33 \\
\hline 67 & $\begin{array}{l}\text { Nintedanib reduces pulmonary fibrosis in a model of } \\
\text { rheumatoid arthritis-associated interstitial lung disease }\end{array}$ & Redente, E. F. & $\begin{array}{l}\text { American Journal of } \\
\text { Physiology-Lung Cellular } \\
\text { and Molecular phy }\end{array}$ & 2018 & 31 & 7.75 \\
\hline 68 & $\begin{array}{c}\text { Profibrotic effect of IL-17A and elevated IL-17RA in } \\
\text { idiopathic pulmonary fibrosis and rheumatoid arthritis- } \\
\text { associated lung disease support a direct role for IL-17A/IL- } \\
\text { 17RA in human fib }\end{array}$ & Zhang, J. & $\begin{array}{l}\text { American Journal of } \\
\text { Physiology-Lung Cellular } \\
\text { and Molecular phy }\end{array}$ & 2019 & 30 & 10 \\
\hline 69 & $\begin{array}{l}\text { Variable course of disease of rheumatoid arthritis- } \\
\text { associated usual interstitial pneumonia compared to other } \\
\text { subtypes }\end{array}$ & Nurmi, H. M. & BMC Pulmonary Medicine & 2016 & 30 & 5 \\
\hline 70 & $\begin{array}{l}\text { Risk of interstitial lung disease associated with leflunomide } \\
\text { treatment in Korean patients with rheumatoid arthritis }\end{array}$ & Ju, J. H. & Arthritis and Rheumatism & 2007 & 30 & 2 \\
\hline 71 & $\begin{array}{l}\text { Anti-cyclic citrullinated peptide antibody is associated with } \\
\text { interstitial lung disease in patients with rheumatoid } \\
\text { arthritis }\end{array}$ & Yin, Y. F. & PLos one & 2014 & 29 & 3.63 \\
\hline 72 & $\begin{array}{l}\text { A novel model of rheumatoid arthritis-associated } \\
\text { interstitial lung disease in SKG mice }\end{array}$ & Keith, R. C. & Experimental Lung Research & 2012 & 29 & 2.9 \\
\hline 73 & $\begin{array}{l}\text { Treatment strategies for a rheumatoid arthritis patient with } \\
\text { interstitial lung disease }\end{array}$ & Kelly, C. & $\begin{array}{l}\text { Expert Opinion on } \\
\text { Pharmacotherapy }\end{array}$ & 2008 & 28 & 2 \\
\hline 74 & $\begin{array}{l}\text { Rheumatoid arthritis disease activity predicting incident } \\
\text { clinically apparent rheumatoid arthritis-associated } \\
\text { interstitial lung disease: a prospective cohort study }\end{array}$ & Sparks, J. A. & Arthritis \& Rheumatology & 2019 & 27 & 9 \\
\hline 75 & $\begin{array}{c}\text { Changes in peripheral CD } 19(+) \text { Foxp } 3(+) \text { and CD } 19(+) \\
\text { TGF beta }(+) \text { regulatory B cell populations in rheumatoid } \\
\text { arthritis patients with interstitial lung disease }\end{array}$ & Guo, Y. Y. & Journal of Thoracic Disease & 2015 & 27 & 3.86 \\
\hline 76 & $\begin{array}{l}\text { Interstitial lung disease in patients with rheumatoid } \\
\text { arthritis: spontaneous and drug induced }\end{array}$ & $\begin{array}{l}\text { Hallowell, R. } \\
\text { W. }\end{array}$ & Drugs & 2014 & 27 & 3.38 \\
\hline 77 & $\begin{array}{l}\text { HLA-A } * 31: 01 \text { and methotrexate-induced interstitial } \\
\text { lung disease in Japanese rheumatoid arthritis patients: a } \\
\text { multidrug hypersensitivity marker? }\end{array}$ & Furukawa, H. & $\begin{array}{l}\text { Annals of the Rheumatic } \\
\text { Diseases }\end{array}$ & 2013 & 27 & 3 \\
\hline 78 & $\begin{array}{l}\text { Asymptomatic preclinical rheumatoid arthritis-associated } \\
\text { interstitial lung disease }\end{array}$ & Chen, J. & $\begin{array}{l}\text { Clinical \& Developmental } \\
\text { Immunology }\end{array}$ & 2013 & 27 & 3 \\
\hline 79 & $\begin{array}{l}\text { Rheumatoid arthritis-associated interstitial lung disease } \\
\text { and idiopathic pulmonary fibrosis: shared mechanistic and } \\
\text { phenotypic traits suggest overlapping disease mechanisms }\end{array}$ & Paulin, F. & $\begin{array}{l}\text { Revista de Investigacion } \\
\text { Clinica-Clinical and } \\
\text { Translational Investig }\end{array}$ & 2015 & 26 & 3.71 \\
\hline 80 & $\begin{array}{l}\text { Lymphoid interstitial pneumonia in juvenile rheumatoid- } \\
\text { arthritis }\end{array}$ & Lovell, D. & Journal of Pediatrics & 1984 & 26 & 0.68 \\
\hline 81 & $\begin{array}{c}\text { Ultrasound screening for interstitial lung disease in } \\
\text { rheumatoid arthritis }\end{array}$ & $\begin{array}{l}\text { Moazedi- } \\
\text { Fuerst, F. C. }\end{array}$ & $\begin{array}{l}\text { Clinical and Experimental } \\
\text { Rheumatology }\end{array}$ & 2014 & 25 & 3.13 \\
\hline
\end{tabular}


TABLE 2: Continued.

\begin{tabular}{|c|c|c|c|c|c|c|}
\hline Rank & Title & Author & Journal & Year & $\begin{array}{l}\text { Total } \\
\text { citation }\end{array}$ & $\begin{array}{l}\text { Citation/ } \\
\text { year }\end{array}$ \\
\hline 82 & $\begin{array}{l}\text { Interstitial pneumonia due to cytomegalovirus following } \\
\text { low-dose methotrexate treatment for rheumatoid-arthritis }\end{array}$ & Aglas, F. & Arthritis and Rheumatism & 1995 & 25 & 0.93 \\
\hline 83 & $\begin{array}{c}\text { Therapeutic management of patients with rheumatoid } \\
\text { arthritis and associated interstitial lung disease: case report } \\
\text { and literature review }\end{array}$ & $\begin{array}{l}\text { Diamanti, A. } \\
\text { P. }\end{array}$ & $\begin{array}{l}\text { Therapeutic Advances in } \\
\text { Respiratory Disease }\end{array}$ & 2017 & 24 & 4.8 \\
\hline 84 & $\begin{array}{l}\text { Interstitial lung disease in rheumatoid arthritis: response to } \\
\text { IL-6R blockade }\end{array}$ & Mohr, M. & $\begin{array}{l}\text { Scandinavian Journal of } \\
\text { Rheumatology }\end{array}$ & 2011 & 24 & 2.18 \\
\hline 85 & $\begin{array}{l}\text { Tocilizumab therapy in rheumatoid arthritis with } \\
\text { interstitial lung disease: a multicentre retrospective study }\end{array}$ & Manfredi, A. & Internal Medicine Journal & 2020 & 23 & 11.5 \\
\hline 86 & $\begin{array}{c}\text { Recent advances in the pathogenesis, prediction, and } \\
\text { management of rheumatoid arthritis-associated interstitial } \\
\text { lung disease }\end{array}$ & Johnson, C. & $\begin{array}{l}\text { Current Opinion in } \\
\text { Rheumatology }\end{array}$ & 2017 & 23 & 4.6 \\
\hline 87 & $\begin{array}{c}\text { Abatacept therapy in rheumatoid arthritis with interstitial } \\
\text { lung disease }\end{array}$ & $\begin{array}{l}\text { Mera-Varela, } \\
\text { A. }\end{array}$ & $\begin{array}{l}\text { Journal of Clinical } \\
\text { Rheumatology }\end{array}$ & 2014 & 23 & 2.88 \\
\hline 88 & $\begin{array}{c}\text { The clinical significance of HRCT in evaluation of patients } \\
\text { with rheumatoid arthritis-associated interstitial lung } \\
\text { disease: a report from China }\end{array}$ & Zou, Y. Q. & Rheumatology International & 2012 & 23 & 2.3 \\
\hline 89 & $\begin{array}{c}\text { A case of adalimumab-associated interstitial pneumonia } \\
\text { with rheumatoid arthritis }\end{array}$ & Yamazaki, H. & Modern Rheumatology & 2010 & 23 & 1.92 \\
\hline 90 & $\begin{array}{l}\text { Prevalence and effects of emphysema in never-smokers } \\
\text { with rheumatoid arthritis interstitial lung disease }\end{array}$ & Jacob, J. & Ebiomedicine & 2018 & 22 & 5.5 \\
\hline 91 & $\begin{array}{l}\text { Association of disease activity with acute exacerbation of } \\
\text { interstitial lung disease during tocilizumab treatment in } \\
\text { patients with rheumatoid arthritis: a retrospective, case- } \\
\text { control study }\end{array}$ & Akiyama, M. & Rheumatology International & 2016 & 22 & 3.67 \\
\hline 92 & $\begin{array}{l}\text { Predicting outcomes in rheumatoid arthritis related } \\
\text { interstitial lung disease }\end{array}$ & Jacobt, J. & $\begin{array}{l}\text { European Respiratory } \\
\text { Journal }\end{array}$ & 2019 & 21 & 7 \\
\hline 93 & $\begin{array}{l}\text { Plasma miRNA expression profiles in rheumatoid arthritis } \\
\text { associated interstitial lung disease }\end{array}$ & Oka, S. & $\begin{array}{l}\text { BMC Musculoskeletal } \\
\text { Disorders }\end{array}$ & 2017 & 21 & 4.2 \\
\hline 94 & $\begin{array}{c}\text { Patients with limited rheumatoid arthritis-related } \\
\text { interstitial lung disease have a better prognosis than those } \\
\text { with extensive disease }\end{array}$ & Sathi, N. & Rheumatology & 2011 & 21 & 1.91 \\
\hline 95 & $\begin{array}{l}\text { Risk of serious infection in patients with rheumatoid } \\
\text { arthritis-associated interstitial lung disease }\end{array}$ & $\begin{array}{l}\text { Zamora- } \\
\text { Legoff, J. A. }\end{array}$ & Clinical Rheumatology & 2016 & 20 & 3.33 \\
\hline 96 & $\begin{array}{l}\text { Possible effect of abatacept on the progression of interstitial } \\
\text { lung disease in rheumatoid arthritis patients }\end{array}$ & Nakashita, T. & Respiratory Investigation & 2016 & 20 & 3.33 \\
\hline 97 & $\begin{array}{l}\text { Up-to-date information on rheumatoid arthritis-associated } \\
\text { interstitial lung disease }\end{array}$ & Suda, T. & $\begin{array}{l}\text { Clinical Medicine Insights- } \\
\text { Circulatory Respiratory and } \\
\text { Pulmonary }\end{array}$ & 2015 & 20 & 2.86 \\
\hline 98 & $\begin{array}{l}\text { Eternacept for the treatment of patients with rheumatoid } \\
\text { arthritis and concurrent interstitial lung disease }\end{array}$ & Horai, Y. & $\begin{array}{l}\text { Journal of Clinical } \\
\text { Pharmacy and Therapeutics }\end{array}$ & 2012 & 20 & 2 \\
\hline 99 & $\begin{array}{l}\text { Myofibroblasts and S-100 protein positive cells in } \\
\text { idiopathic pulmonary fibrosis and rheumatoid arthritis- } \\
\text { associated interstitial pneumonia }\end{array}$ & $\begin{array}{l}\text { Yoshinouchi, } \\
\text { T. }\end{array}$ & $\begin{array}{l}\text { European Respiratory } \\
\text { Journal }\end{array}$ & 1999 & 20 & 0.87 \\
\hline 100 & $\begin{array}{l}\text { The performance of the GAP model in patients with } \\
\text { rheumatoid arthritis associated interstitial lung disease }\end{array}$ & Morisset, J. & Respiratory Medicine & 2017 & 19 & 3.8 \\
\hline
\end{tabular}

In addition to its impact on the quality of life, RA-ILD places a huge burden on the medical system, with an average total medical cost of more than $\$ 170,000$ per patient over five years [8]. Our statistical and quantitative analysis shows a gradual increase in RA-ILD research results from 2011 to 2020, with more researchers and physicians focusing on this area of research. Despite the wide range of RA-ILD research, an analysis of the current status and trends in RA-ILD research is not clear. In this study, we analyzed, discussed, and described the current status, priorities, and trends of RA-ILD research. At the same time, our study will help RA-ILD researchers gain a more comprehensive understanding of the current state of RA-ILD research and thus guide the direction of future research. 


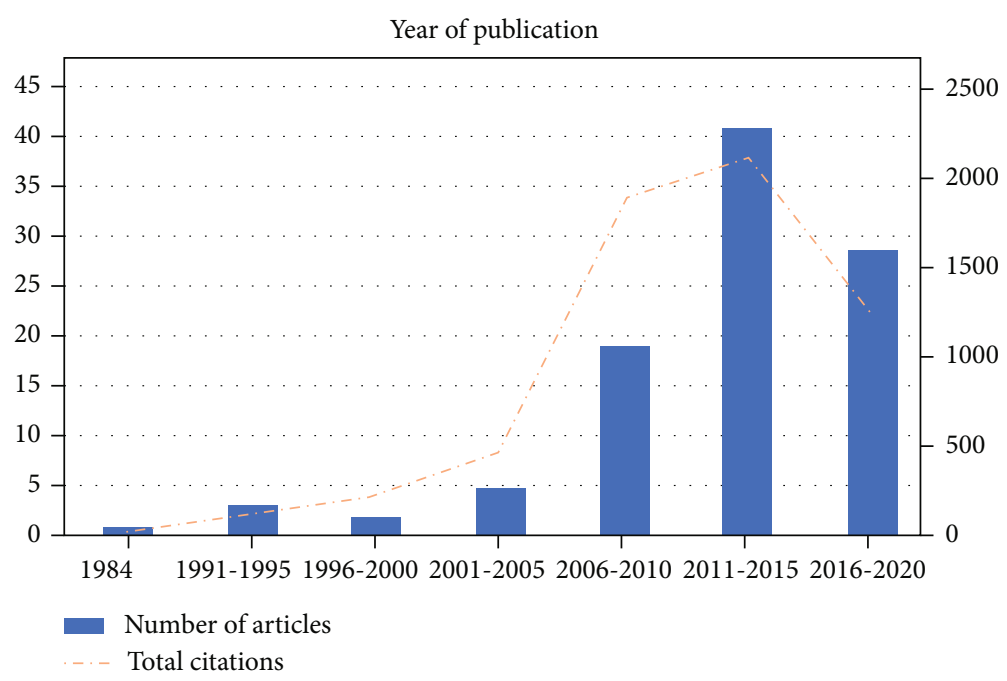

(a)

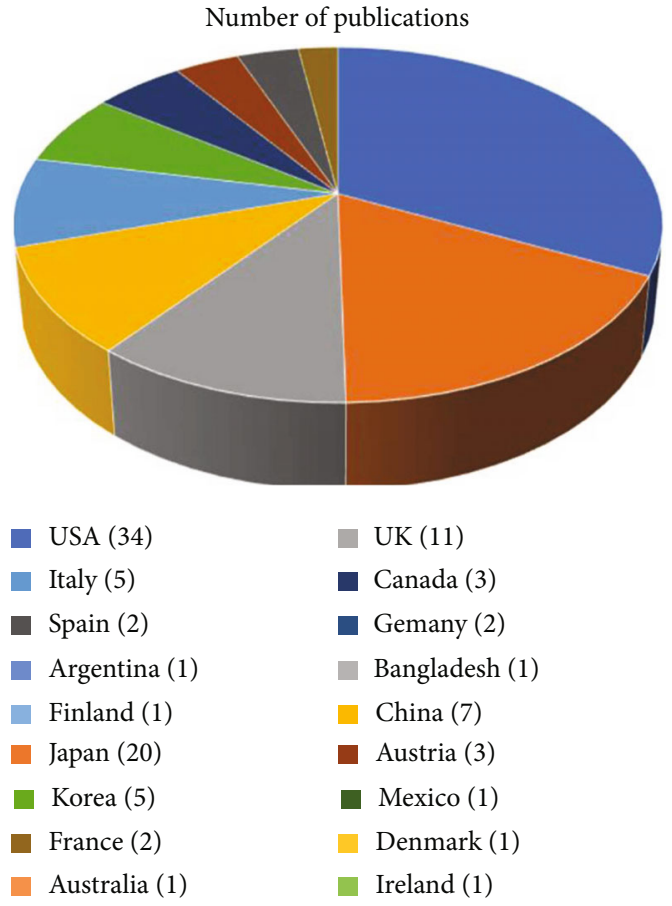

(b)

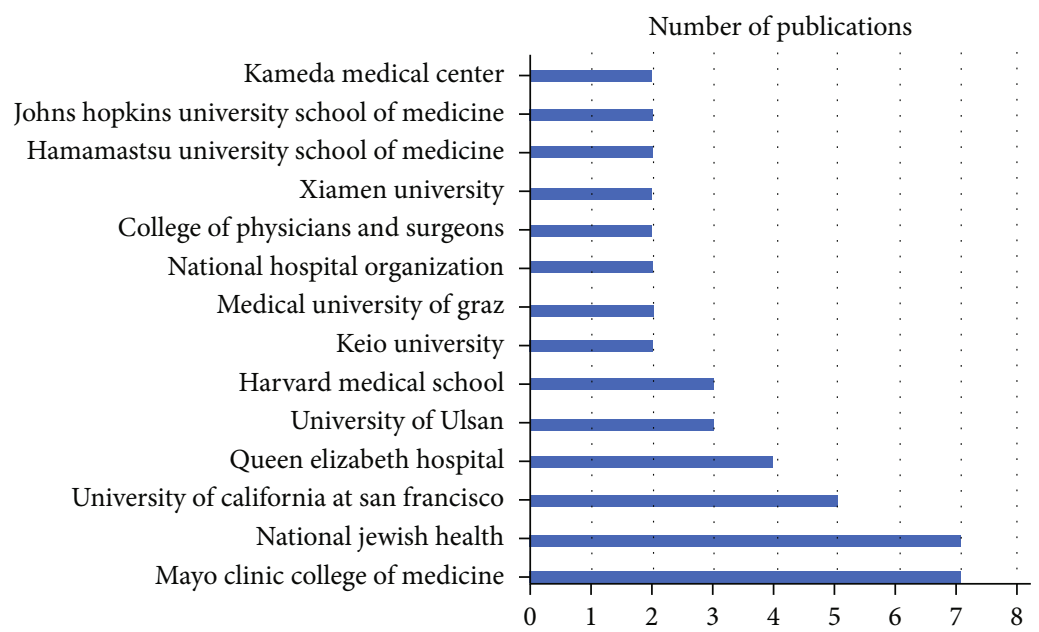

(c)

FIgURE 4: Continued. 


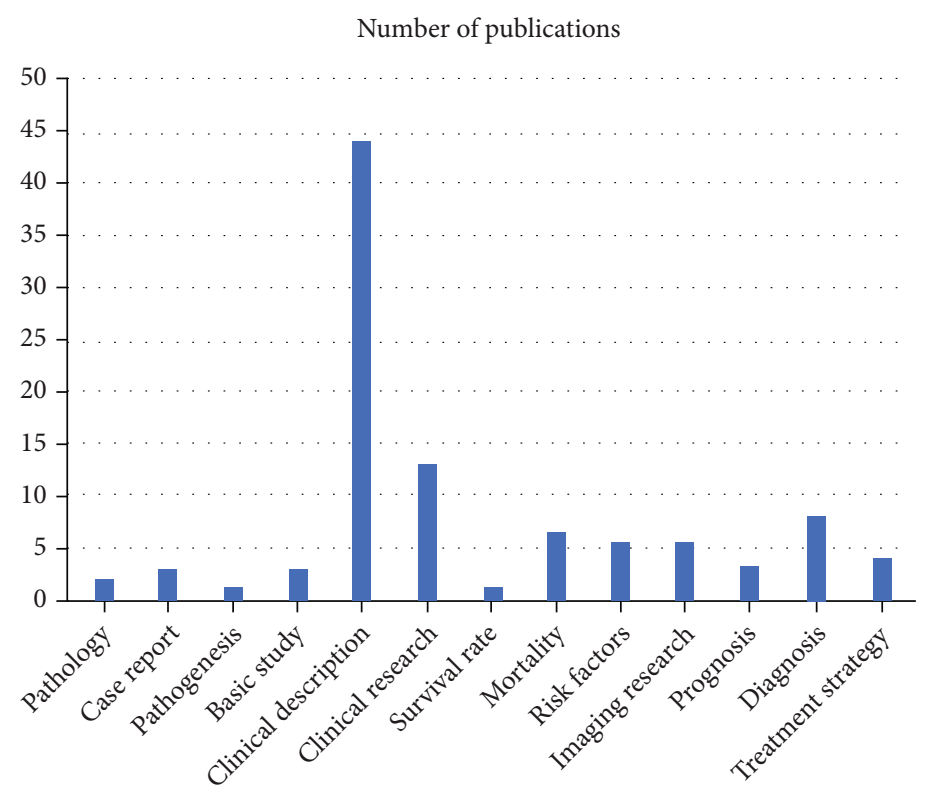

(d)

FIGURE 4: Top 100 most-cited publications on RA-ILD. (a) Year of publication. (b) Distribution of country. (c) Institution analysis. (e) Publication topics.

TABLE 3: Journal with more than three of the 100 most-cited publications on rheumatoid arthritis-associated interstitial lung disease.

\begin{tabular}{lcccc}
\hline Journal & Article & Total citation & Mean citation & Impact factor \\
\hline Rheumatology & 8 & 632 & 79 & 105.8 \\
Arthritis and Rheumatism & 5 & 529 & 41.4 & 5.532 \\
Clinical Rheumatology & 5 & 207 & 103.4 & 4.098 \\
European Respiratory Journal & 5 & 517 & 72.25 & 16.671 \\
Annals of the Rheumatic Diseases & 4 & 289 & 47.75 & 19.103 \\
Arthritis \& Rheumatology & 4 & 191 & 55.75 & 3.772 \\
Respiratory Medicine & 4 & 135 & 33.75 & 2.631 \\
Rheumatology International & 4 & 223 & \\
\hline
\end{tabular}

4.1. Publication Trends in RA-ILD Research. The number of articles related to RA-ILD has increased rapidly over the last 10 years. Globally, the USA ranks first in terms of the number of publications and citations, indicating that the USA has led to research on RA-ILD in the past few years. In terms of institutional contributions, the institution with the highest publication output is the Mayo Clinic (USA) and ranked first in the total citations. This reflects the institution's leadership in the field of RA-ILD research. Analysis of cooperation between countries and institutions shows that regional clusters are usually geographically specific. As a leader in the world economy and science, the USA has the most frequent cooperation with Japan, France, China, and South Korea. Researchers working on RA-ILD should pay close attention to them and collaborate with these institutions and countries. Annals of the Rheumatic Diseases, Arthritis \& Rheumatology, American Journal of Respiratory and Critical Care Medicine, Rheumatology, and Arthritis and Rheumatism are the five most prolific journals in RA-ILD.
4.2. Research Foci. Keyword analysis results showed that RAILD, rheumatoid arthritis, interstitial lung disease, and pneumonia were keyword cluster centers. In the early stages, "idiopathic pulmonary fibrosis," "alveolitis," and "systemic sclerosis" were the main topics. In recent years, more common keywords have included "management," "predictors," "inflammation," and "progression."

4.3. The Most-Cited Articles. The most-cited publication in RA-ILD was the 2010 article in Arthritis and Rheumatism by Bongartz et al. with 324 citations: "Incidence and mortality of interstitial lung disease in rheumatoid arthritis: a population-based study," which introduced incidence, risk factors, and mortality of RA-ILD [2]. The mean follow-up time of 582 RA patients and 603 non-RA patients was 16.4 years and 19.3 years, respectively. The lifetime risk of ILD was $7.7 \%$ in patients with rheumatoid arthritis and $0.9 \%$ in those without rheumatoid arthritis. Studies have shown that the prevalence of ILD is higher in older male patients and in 
TABLE 4: Most frequent authors of the 100 most-cited publications on rheumatoid arthritis-associated interstitial lung disease.

\begin{tabular}{lcccc}
\hline Author & Article & $\begin{array}{c}\text { First } \\
\text { author }\end{array}$ & $\begin{array}{c}\text { Last } \\
\text { author }\end{array}$ & $\begin{array}{c}\text { Co- } \\
\text { author }\end{array}$ \\
\hline Ryu, Jay H. & 11 & 0 & 0 & 0 \\
Lee, Joyce S. & 8 & 0 & 2 & 6 \\
Matteson, Eric L. & 8 & 2 & 4 & 2 \\
Brown, Kevin K. & 6 & 0 & 2 & 4 \\
Collard, Harold R. & 6 & 0 & 1 & 5 \\
Kelly, Clive A. & 6 & 2 & 4 & 0 \\
Kim, Dong Soon. & 6 & 1 & 1 & 4 \\
Rosas, Ivan O. & 6 & 0 & 3 & 3 \\
Solomon, Joshua J. & 6 & 2 & 1 & 3 \\
Doyle, Tracy J. & 5 & 2 & 1 & 1 \\
Ascherman, Dana P. & 5 & 0 & 2 & 3 \\
Fischer, Aryeh. & 5 & 0 & 0 & 0 \\
Swigris, Jeffrey J. & 5 & 0 & 2 & 3 \\
\hline
\end{tabular}

individuals with more severe RA parameters. RA patients diagnosed with ILD have poorer survival than RA patients without ILD, and ILD accounts for approximately $13 \%$ of the excess mortality in RA patients compared to the general population.

"Usual interstitial pneumonia in rheumatoid arthritisassociated interstitial lung disease" by Kim et al. in 2010 was the second most-cited article with 283 citations [16]. The authors determined that the pattern of common interstitial pneumonia (IP) found on high-resolution computed tomography (HRCT) is important for the prognosis of RAILD. Eighty-two patients with RA-ILD were identified retrospectively. "We determined the relationship between survival and the pattern of IP common on HRCT and compared it with patients diagnosed radiologically with idiopathic pulmonary fibrosis. Twenty (24\%) of the 82 patients with RA-ILD had definite common IP. Survival in patients with RA-ILD was lower than that in patients without this pattern, similar to the survival of patients with idiopathic pulmonary fibrosis. In addition, a clear pattern of common IP on HRCT was associated with poor survival. Analysis of feature-specific HRCTs showed that traction bronchiectasis and cellular fibrosis were associated with poor survival. Women and a higher baseline carbon monoxide lung diffusing capacity were associated with better survival."

"Histopathological and clinical features of interstitial lung disease associated with rheumatoid arthritis" by Lee et al. was the third most-cited article with 245 citations [25]. The authors studied the histopathological patterns and clinical characteristics of patients with RA-ILD according to the American Thoracic Society/European Respiratory Society consensus classification of idiopathic IP. "Eighteen patients with RA who underwent surgical lung biopsy for suspected ILD were included in this study. This study revealed diverse histopathological findings. Ten patients had a common interstitial pneumonia (UIP) pattern, six patients had a nonspecific interstitial pneumonia (NSIP) pattern, and two patients had inflammatory airway disease with tissue-type pneumonia.
Thus, the UIP pattern appears to be more common than the NSIP pattern in our study population."

4.4. Limitations. Our study had several limitations. First, we extracted information related to RA-ILD from the Core Collection database of the Web of Science. It is possible that some influential publications were not included in this database and were therefore excluded from our study. Second, the date of our retrieval and extraction of data was July 1, 2021. Part of the data correspond to dynamic changes, but the trend of changes will not be extensive. Third, we retained only English articles in our search strategy.

\section{Conclusions}

Quantitative analysis showed that in the past 10 years, global research on RA-ILD has increased rapidly. Of all the countries, the USA publishes most articles on RA-ILD.

The USA has contributed the most to the RA-ILD literature. Mayo Clinic, National Jewish Health, Brigham and Women's Hospital, Colorado State University, and University of California, San Francisco are the most prolific institutions associated with RA-ILD research. Annals of the Rheumatic Diseases, Arthritis \& Rheumatology, American Journal of Respiratory and Critical Care Medicine, Rheumatology, and Arthritis and Rheumatism are the top five most popular journals on RA-ILD publications.

\section{Conflicts of Interest}

The authors declare that they have no conflicts of interest.

\section{Authors' Contributions}

Yuan Zhang, Tingxiao Zhao, and Tianjin Wu contributed equally to this study.

\section{References}

[1] F. Salaffi, R. de Angelis, W. Grassi, MArche Pain Prevalence, and INvestigation Group (MAPPING) study, "Prevalence of musculoskeletal conditions in an Italian population sample: results of a regional community-based study. I. The MAPPING study," Clinical and Experimental Rheumatology, vol. 23, no. 6, pp. 819-828, 2005.

[2] T. Bongartz, C. M.-V. Nannini, Y. F. Medina-Velasquez et al., "Incidence and mortality of interstitial lung disease in rheumatoid arthritis: a population-based study," Arthritis and Rheumatism, vol. 62, no. 6, pp. 1583-1591, 2010.

[3] A. Balbir-Gurman, M. Yigla, A. M. Nahir, and Y. Braun-Moscovici, "Rheumatoid pleural effusion," in Seminars in arthritis and rheumatism, vol. 35, no. 6, 2006WB Saunders, 2006.

[4] J. P. Corcoran, M. Ahmad, R. Mukherjee, and K. C. Redmond, "Pleuro-pulmonary complications of rheumatoid arthritis," Respiratory Care, vol. 59, no. 4, pp. e55-e59, 2014.

[5] C. Nannini, J. H. Ryu, and E. L. Matteson, "Lung disease in rheumatoid arthritis," Current Opinion in Rheumatology, vol. 20, no. 3, pp. 340-346, 2008.

[6] P. Spagnolo, J. S. Lee, N. Sverzellati, G. Rossi, and V. Cottin, "The lung in rheumatoid arthritis," Arthritis \& Rheumatology, vol. 70, no. 10, pp. 1544-1554, 2018. 
[7] J. J. Solomon, J. H. Chung, G. P. Cosgrove et al., "Predictors of mortality in rheumatoid arthritis-associated interstitial lung disease," European Respiratory Journal, vol. 47, no. 2, pp. 588-596, 2016.

[8] K. Raimundo, J. J. Solomon, A. L. Olson et al., "Rheumatoid arthritis-interstitial lung disease in the United States: prevalence, incidence, and healthcare costs and mortality," The Journal of Rheumatology, vol. 46, no. 4, pp. 360-369, 2019.

[9] J. J. Solomon, J. J. Swigris, M. Kreuter et al., "The attitudes and practices of physicians caring for patients with rheumatoid arthritis-associated interstitial lung disease: an international survey," Rheumatology, 2021.

[10] A. Saku, T. Fujisawa, K. Nishimoto et al., "Prognostic significance of peripheral blood monocyte and neutrophil counts in rheumatoid arthritis-associated interstitial lung disease," Respiratory Medicine, vol. 182, article 106420, 2021.

[11] M. Zheng, A. Lou, H. Zhang, S. Zhu, M. Yang, and W. Lai, "Serum KL-6, CA19-9, CA125 and CEA are diagnostic biomarkers for rheumatoid arthritis-associated interstitial lung disease in the Chinese population," Rheumatology and Ther$a p y$, vol. 8, no. 1, pp. 517-527, 2021.

[12] Y. Dai, W. Wang, Y. Yu, and S. Hu, "Rheumatoid arthritisassociated interstitial lung disease: an overview of epidemiology, pathogenesis and management," Clinical Rheumatology, vol. 40, no. 4, pp. 1211-1220, 2021.

[13] J. Tu, P. C. Brennan, S. Lewis, and S. Tavakoli Taba, "A bibliometric and social network analysis perspective of X-ray phasecontrast imaging in medical imaging," Journal of Medical Radiation Sciences, 2021.

[14] X. Zou and Y. Sun, "Bibliometrics analysis of the research status and trends of the association between depression and insulin from 2010 to 2020," Frontiers in Psychiatry, vol. 12, 2021.

[15] K. Y. Liao, Y. H. Wang, H. C. Li, T. J. Chen, and S. J. Hwang, "COVID-19 publications in family medicine journals in 2020: a PubMed-based bibliometric analysis," International Journal of Environmental Research and Public Health, vol. 18, no. 15, p. 7748, 2021.

[16] E. J. Kim, B. M. Elicker, F. Maldonado et al., "Usual interstitial pneumonia in rheumatoid arthritis-associated interstitial lung disease," European Respiratory Journal, vol. 35, no. 6, pp. 1322-1328, 2010.

[17] A. L. Olson, J. J. Swigris, D. B. Sprunger et al., "Rheumatoid arthritis-interstitial lung disease-associated mortality," American Journal of Respiratory and Critical Care Medicine, vol. 183, no. 3, pp. 372-378, 2011.

[18] E. Gabbay, R. Tarala, R. Will et al., "Interstitial lung disease in recent onset rheumatoid arthritis," American Journal of Respiratory and Critical Care Medicine, vol. 156, no. 2, pp. 528-535, 1997.

[19] H. M. Habib, A. A. Eisa, W. R. Arafat, and M. A. Marie, "Pulmonary involvement in early rheumatoid arthritis patients," Clinical Rheumatology, vol. 30, no. 2, pp. 217-221, 2011.

[20] G. Koduri, S. Norton, A. Young et al., "Interstitial lung disease has a poor prognosis in rheumatoid arthritis: results from an inception cohort," Rheumatology, vol. 49, no. 8, pp. 1483$1489,2010$.

[21] C. A. Kelly, V. Saravanan, M. Nisar et al., "Rheumatoid arthritis-related interstitial lung disease: associations, prognostic factors and physiological and radiological characteristics-a large multicentre UK study," Rheumatology, vol. 53, no. 9, pp. 1676-1682, 2014.
[22] J. A. Sparks, X. He, J. Huang et al., "Rheumatoid arthritis disease activity predicting incident clinically apparent rheumatoid arthritis-associated interstitial lung disease: a prospective cohort study," Arthritis \& Rheumatology, vol. 71, no. 9, pp. 1472-1482, 2019.

[23] P. Kiely, A. D. Busby, E. Nikiphorou et al., "Is incident rheumatoid arthritis interstitial lung disease associated with methotrexate treatment? Results from a multivariate analysis in the ERAS and ERAN inception cohorts," BMJ Open, vol. 9, no. 5, article e028466, 2019.

[24] M. Shaw, B. F. Collins, L. A. Ho, and G. Raghu, "Rheumatoid arthritis-associated lung disease," European Respiratory Review, vol. 24, no. 135, pp. 1-16, 2015.

[25] H. K. Lee, D. S. Kim, B. Yoo et al., "Histopathologic pattern and clinical features of rheumatoid arthritis-associated interstitial lung disease," Chest, vol. 127, no. 6, pp. 2019-2027, 2005. 